Fourth, that instead of pulmonary tuberculosis having a special preference for the bones, joints, and glands in childhood, the tuberculous process in these regions and tissues would appear to be secondary to the involvement of the lung, and to represent a residual stage of a generalized infection. Fifth, that even the glandular forms of tuberculosis do not represent an earlier or milder form of the infection, but are secondary to a pulmonary involvement. Sixth, that the moderate but appreciable degree of immunity against pulmonary tuberculosis possessed by children who have manifested osseous, articular, or glandular forms of the disease is possibly to be interpreted on the theory that they have already survived a considerable clegree of pulmonary involvement. Seventh, that such immunity as may be acquired by civilized races is probably like the immunity of the negro races to malaria, the result of the survival of attacks of the pulmonary form of the disease in childhood.

\title{
SYSTEMATIC EXAMINATION OF EMPLOYEES FOR TUBERCULOSIS.
}

\author{
By THEODORE B. SACHS, \\ M.D.; \\ Chairman of the Advisory Committee on Factories of the Chicago \\ Tuberculosis Institute.
}

PERIODIC examination of machinery is a part of the business policy of all well-managed establishments. Serious damage, or even total destruction, results from neglect of timely repair. Entailment of a small expense to-day means prevention of a larger expense, or possibly of total loss, to-morrow. This policy of periodic examination, intended to stop leaks, to repair slight damage, to prevent irreparable deterioration, is applicable at present to all " inanimate " machinery. "Human" machinery is just beginning to receive the gradually increasing proportion of attention due to it.

It is readily understood that knowledge of the physical condition of a worker is of great importance to the employer, as health is a factor in determining productive efficiency. The period of usefulness of employees is lengthened through a system of examinations designed for detection of breaks in their physical condition, and a policy of extension of leaves of absence at a time when "repair" is possible. It is in the interest of every business man to take stock of the hẹalth of his employees, if for no other reason than for the determination of their 
working capacity and prevention of total disability, which results in the loss of tried and experienced men.

In the detection of no other disease does the economic gain to the employer from this procedure stand out as prominently as in the case of pulmonary tuberculosis, with its gradual and at first imperceptible impairment of the productive capacity of the worker. The early detection of this disease in an employee is of great importance to himself, and also to his co-workers and his employer.

The chance of ultimate "cure" or "arrest," as well as restoration of the working capacity, gradually diminishes with the growth of the disease. The possibility of infecting others grows with the gradual transformation of a "closed" incipient lesion into an "open" one, with its swarm of tubercle bacilli in the sputum. The interests of the employer are alike vitally affected by the gradual diminution of the productive capacity of a tuberculous employee and of those subsequently infected.

These considerations call for a system of medical examinations of employees in all working-places, as a necessary measure for the protection of all concerned. The expense entailed in the maintenance of such examinations is far outbalanced by the benefits derived.

It is highly desirable that all employees should be examined for traces of tuberculosis, and it is possible that, with the present tendencies in our system of government, the State may eventually make provision for this purpose. Until then, however, the interests of the employer necessitate the conduct of such examinations at his own expense.

To test for evidences of tuberculosis every applicant for a position would entail a considerable outlay of money, though in a number of manufacturing and commercial establishments a large percentage of employees are given at present a thorough medical examination before their admission to those benevolent associations which are connected with their work.

In Chicago, numerous firms provide general medical service for attendance on employees falling sick during their term of employment. Special attention is given to tuberculosis in the shops of Sears, Roebuck and Co., Montgomery, Ward and Co., and the International Harvester Company, three firms well known for their welfare work among employees. These firms have built and maintain special cottages for their employees at the Edward Sanatorium, Naperville, Illinois.

The great prevalence of tuberculosis among working people makes it highly desirable, however, that special medical provision should be organized in large concerns for the early detection of this disease.

To round up every possible case of tuberculosis, without going to the extent of examination of every employee, the following method was proposed to the International Harvester Company, which employs 
about 20,000 workers in the city of Chicago. A list of suspected cases is to be prepared by a special tuberculosis nurse, who has the cooperation of the foreman in charge of various factories of the company, the list to include the following groups of cases: (I) Employees in whom the diagnosis of tuberculosis has been previously made; (2) employees in whom poor general condition in connection with other suspicious symptoms suggests the presence of tuberculous disease; (3) employees with histories of protracted cough and expectoration; (4) employees in whose families a case of tuberculosis exists, or death has occurred from this disease ; etc.

With the compilation of such a list of suspected cases, a special tuberculosis clinic can be inaugurated for the benefit of the employees of the company. This plan was first submitted to the Executive Committee of the Chicago Tuberculosis Institute, and on their approval adopted by the International Harvester Company. Dr. James A. Britton, of this city, and Miss Jane Flanagan, a tuberculosis nurse until recently on the staff of the Chicago Municipal Sanatorium, were placed by the International Harvester Company in charge of the proposed clinic. Beginning with the above-mentioned groups of cases, the system of examination for tuberculosis is to extend gradually to all suspicious cases.

With the inauguration of this first industrial tuberculosis clinic, the Chicago Tuberculosis Institute appointed a special Advisory Committee on Factories, consisting of Dr. Henry B. Favill, Mr. Sherman C. Kingsley, and Dr. Theodore B. Sachs. This committee is to act in advisory relation to the clinic, and has for its purpose the extension of similar provisions to other manufacturing and commercial establishments.

It is agreed that a case of tuberculosis in a working-place should not remain unrecognized, and cannot be permitted to continue uncontrolled. Knowledge of the actual conditions in reference to tuberculosis among their own workers is bound to enlist the active participation of employers of labour in the present crusade against the White Plague, and, we are fully convinced, is destined to improve the entire situation. 